\title{
Homeopathic and Larvicide Effect of Eucalyptus cinerea Essential Oil against Aedes aegypti
}

\author{
Patrícia Aparecida Mançano Cavalca ${ }^{1}$, Maria Isabel Gomes de Assumpção Lolis ${ }^{1}$, Bruno \\ Reis $^{2}$ and Carlos Moacir Bonato ${ }^{1 *}$ \\ ${ }^{1}$ Departamento de Biologia; ${ }^{2}$ Departamento de Agronomia; Universidade Estadual de Maringá; 87020-900; \\ Maringá - PR - Brasil
}

\begin{abstract}
The aim of this work to study the homeopathic and larvicide effect of Eucalyptus cinerea essential oil on Aedes aegypti. Essential oil had high larvicide effect with LC50 and LC90 of 0.38 and $0.27 \mathrm{mg} \mathrm{mL}^{-1}$, respectively. Generally, the homeopathy of essential oil affected the A. aegypti development stages. Dynamizations 6CH, 9CH and $12 \mathrm{CH}$ reduced the mean number of larvae when compared to that of control. Mean number of mosquitoes decreased through homeopathic dynamization 30CH. Results showed that E. cinerea essential oil was highly promising and could be used in public health system for the control of $\mathrm{A}$. aegypti.
\end{abstract}

Key words: Ultra-diluted; secondary metabolism; biomass; homeopathic drugs

\section{INTRODUCTION}

Viral infection dengue, transmitted by the mosquito of the genus Aedes, is one of the main worldwide concerns in public health (Tare et al., 2004; Furtado et al., 2005), especially in tropical and subtropical countries where its incidence is very high (Cavalcanti et al., 2004). An estimated 1.3 billion people were infected with dengue according to WHO (2004). In tropical countries, Aedes aegypti is the main transmitter insect of dengue (Furtado et al., 2005), Dengue infestations have repeatedly occurred in Brazil during the last decade (Cavalcanti et al., 2004). For this, the etiological agent is an arbovirus and the main vector is the Aedes aegypti mosquito which has been found in more than 3600 municipalities in Brazil (Cives, 2002).

Control of the culicide by insecticides such as temephos, malathion and phenitrothion has been the main policy adopted by public health policies (Furtado et al., 2005). However, the indiscriminate use of synthetic insecticides in agriculture and in public policy programs during the last fifty years has established resistance to insecticides, environmental pollution and contamination of humans and other living beings (Thomas et al., 2004). Resistance of the dipteran insect to conventional insecticides (Furtado et al., 2005) has been reported in different countries (Wirth and Georghiou, 1999), including Brazil (Macoris et al., 2003).

Studies with natural products such as insecticides and larvicides have been undertaken for the control of mosquito Aedes, albeit with different results (Rahuman et al. 2000, Markouk et al. 2000, Ciccia et al., 2000, Tsao et al., 2002, Silva et al., 2004; Furtado et al., 2005). There are no reports in the literature on studies investigating the effects of homeopathic medicine on A. aegypti, although

\footnotetext{
*Author for correspondence: cmbonato@uem.br
} 
there are reports on control of pest insects such as Spodoptera frugiperda (Almeida et al., 2003) and Cerotoma tingomarianus (Fazolin et al., 2000).

Thence, the aim of the presente work was to study the larvicide and homeopathic effects of $E$. cinerea essential oil against $A$. aegypti.

\section{MATERIALS AND METHODS}

\section{Determination of larvicide effect of Eucalyptus cinerea oil}

First and fourth instar larvae of A. aegypti hailing from several collections taken in the municipality of Maringá PR Brazil were employed for the bioassays. Essential oil of E. cinerea, obtained by hydro-distillation in steam drags, was diluted in a watery solution of dimethyl sulfoxide (2\% DMSO, Sigma) in 100, 50, 10, 1.0, 0.4, 0.3, 0.2, 0.1 and $0.05 \mathrm{mg} \mathrm{mL}^{-1}$ concentrations. Ten larvae of $A$. aegypti were separated by Pasteur pipette and placed in $500 \mathrm{~mL}$-flasks with $30 \mathrm{~mL}$ of different concentrations of essential oil. Control consisted of a solution with DMSO (2\%). Larvae were fed with previously tested fish diets during the assay.

The number of dead larvae was obtained after larvae had been exposed in different essential oil concentrations for $24 \mathrm{~h}$. Motion-less larvae or those which did not respond to stimuli by pipette were considered as dead. The experimental design was totally randomized, with four concentrations of E. cinerea essential oil, besides control constituted of DMSO (2\%) solution. Four repetitions, totaling 20 experimental runs, were used.

\section{Statistic analysis}

Data were submitted to ANOVA and quantity variables were discriminated by $\mathrm{F}$ test or by regression analysis. Regression data estimated $\mathrm{LC}_{50}$ (lethal concentration that produced $50 \%$ of dead larvae) and $\mathrm{LC}_{90}$ (lethal concentration which caused $90 \%$ of dead larvae exposed to essential oil).

\section{Homeopathic effect of $\boldsymbol{E}$. cinerea oil Production of homeopathy}

Homeopathy drug from E. cinerea oil was prepared according to the Brazilian Homeopathic Pharmacopoeia (1987). Two hundred micro-liters of essential oil were placed in a $19.8 \mathrm{~mL}$ (dilution 1/100) alcohol solution (5\%) and shaken 100 times for the first homeopathic dynamization $(1 \mathrm{CH}-$
Centesimal Hahnemannian). Dynamizations $3 \mathrm{CH}$, $6 \mathrm{CH}, 9 \mathrm{CH}, 12 \mathrm{CH}$ and $30 \mathrm{CH}$ were obtained in successive dilutions and stored for later use.

\section{Bioassay}

Ten $1^{\text {st }}$ and $2^{\text {nd }}$ instar larvae (between 0.2 and 0.4 $\mathrm{cm})$, were separated with Pasteur pipette and placed in flasks with $30 \mathrm{~mL}$ of drinking water and fish diet as feed. Two hundred micro-liters of different homeopathic dynamizations $(3 \mathrm{CH}, 6 \mathrm{CH}$, $9 \mathrm{CH}, 12 \mathrm{CH}$ and $30 \mathrm{CH})$, besides control $(200 \mu \mathrm{L}$ alcohol 5\%), were placed in each experimental unit. Flasks were covered with a tulle-like cloth to prevent adult insects from escaping. Experimental units were placed in a dark-light environment, at a temperature of about $25^{\circ} \mathrm{C}$. The number of larvae, pupae and adults was counted daily during 12 consecutive days. Randomized experimental design consisted of five dynamizations of $E$. cinerea essential oil $(3 \mathrm{CH}, 6 \mathrm{CH}, 9 \mathrm{CH}, 12 \mathrm{CH}$ and $30 \mathrm{CH}$ ) and control (ethanol solution (5\%), without dynamization), totaling 24 experimental runs. Data were submitted to ANOVA and interaction dynamization versus time was discriminated by $\mathrm{F}$ test.

\section{RESULTS AND DISCUSSION}

Mortality of A. aegypti larvae rose proportionately to increase in essential oil concentrations in incubation medium (Fig. $1 \mathrm{~A}$ and B). Survival of larvae in concentration 0 to $1 \mathrm{mg} \mathrm{mL}^{-1}$ ranged from more than $90 \%$ to approximately $25 \%$. Larvicide potential of essential oil is shown in Fig. 1A. Larvae mortality reached $100 \%$ starting from $1 \mathrm{mg} \mathrm{mL}^{-1}$ (Fig. 1A). The same trend was found when lesser concentrations ( 0 to $1.0 \mathrm{mg} \mathrm{mL}^{-1}$ ) were used. Consequently, larvae mortality was proportional to the increase of essential oil concentrations. No movement in stimulated larvae was seen with over $0.4 \mathrm{mg} \mathrm{mL}^{-1}$ concentrations (Fig. 1B). Larvae died instantly when placed in contact with concentrations over $1 \mathrm{mg} \mathrm{mL}^{-1}$.

Since concentrations up to $1.0 \mathrm{mg} \mathrm{ml}^{-1}$ were extremely lethal to larvae, lower concentrations, varying between 0 and $0.4 \mathrm{mg} \mathrm{mL} \mathrm{mL}^{-1}$, were employed (Fig. 1B). And the lethal concentration that caused the death of $50 \%\left(\mathrm{LC}_{50}\right)$ and $90 \%$ $\left(\mathrm{LC}_{90}\right)$ of larvae was identified (Fig. 2).

Best survival as a function of essential oil dose could be explained by the exponential regression (Fig. 3). A progressive decrease was found in 
larvae survival in proportion to increase in concentration of essential oil of the incubation medium. Concentration estimated by equation $(\mathrm{y}=$ $\left.-543.1 x^{2}-11.558 x+93.571\right)$ which was capable of causing the death of $50 \%\left(\mathrm{LC}_{50}\right)$ and $90 \%$ $\left(\mathrm{LC}_{90}\right)$, were 0.27 and $0.38 \mathrm{mg} \mathrm{mL}^{-1}$, respectively (Fig. 2).

Furtado et al. (2005) studied the effect essential oils of Ageratum conyzoides L., Cymbopogom citratus Stapf, Lippia sidoides Chamisso, Ocimum gratissimum L., Ocimum basilicum purpurascens Benth, Ocimum tenuiflorum L., Cymbopogon winterianus Jowitt, Tagetes minuta L., Vanillosmopsis arborea Baker, Citrus limon L. on A. aegypti larvae. V. arborea essential oil caused the highest larvicide effect with $\mathrm{LC}_{50}$ of $15.9 \mathrm{mg}$ $\mathrm{mL}^{-1}$ and $\mathrm{LC}_{90}$ of $28.5 \mathrm{mg} \mathrm{mL}^{-1}$; O. gratissimum $\mathrm{L}$. essential oil showed the least activity with $\mathrm{LC}_{50}$ of $95.80 \mathrm{mg} \mathrm{mL}^{-1}$ and $\mathrm{LC}_{90}$ of $102.86 \mathrm{mg} \mathrm{mL}^{-1}$.
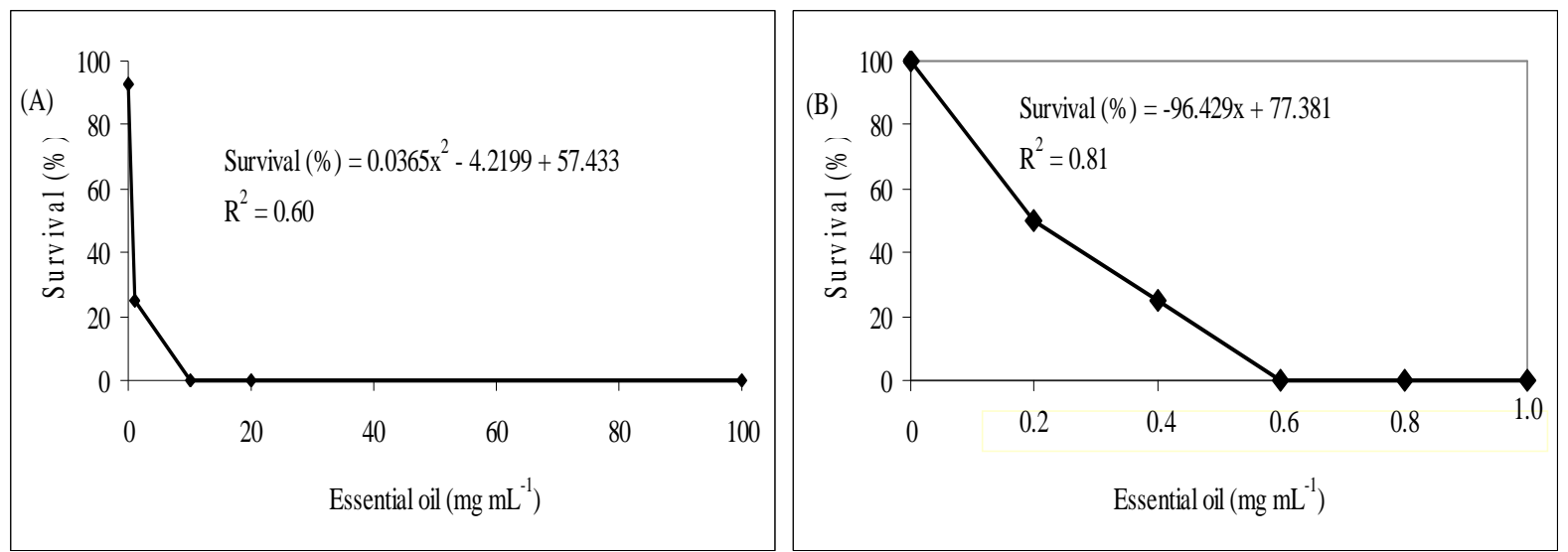

Figure 1 - Effect of Eucalyptus cinerea essential oil on percentage of Aedes aegypti larvae survival. (A) concentration between 0 and $100 \mathrm{mg} \mathrm{mL}^{-1}(\mathrm{~B})$ - concentration between 0 and $1 \mathrm{mg} \mathrm{mL} \mathrm{mL}^{-1}$. $(\mathrm{p}<0.001$ by $\mathrm{F}$ test $)$.

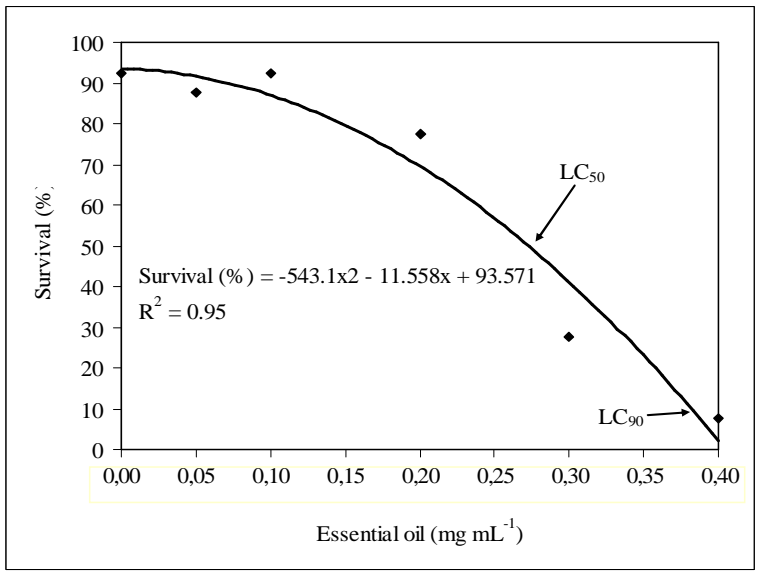

Figure 2 - Exponential regression of survival percentage of Aedes aegypti larvae as a function of Eucalyptus cinerea essential oil concentration ( $\mathrm{p}<0.001$ by $\mathrm{F}$ test).

However, results with E. cinerea essential oil were higher than the above. E. cinerea essential oil approximately 60 times lower $\mathrm{LC}_{50}(15.8$ against $\left.0.27 \mathrm{mg} \mathrm{mL}^{-1}\right)$ and 75 times lower $\mathrm{LC}_{90}(0.38$ against $28.5 \mathrm{mg} \mathrm{mL}^{-1}$ ). Nevertheless, other authors have also reported the strong effect of other essential oils. Araujo et al. (2003) found that essential oil of Hyptis martiusii leaves at $500 \mathrm{ppm}$ concentrations caused the death of all larvae. Cavalcanti et al. (2004) reported that the essential 
oil of Ocimum americanum and $O$. gratissimum showed $\mathrm{LC}_{50}$ of 67 and $60 \mathrm{ppm}$, respectively. In the case of Lippia sidoides and Cymbopogon citratus, $\mathrm{LC}_{50}$ was $63 \mathrm{ppm}$ in the former and 69 ppm in the latter. Thomas et al. (2004) used essential oil of the native herb Ipomoea cairica and obtained $\mathrm{LC}_{50}$ and $\mathrm{LC}_{90}$ with 22.3 and 92.7 ppm, respectively.

Since essential oils are a complex mixture of compounds, they fail to show a precisely definite larvicide mechanism. Suggested mechanisms include protein denaturalization, enzymatic inhibition and membrane disintegration, with a probable interaction between oil components which cause synergism and/or antagonism (Janssen, 1989). According to Cowan (1999), main compounds in eucalyptus are tannins of the polyphenol class and terpenoids present in essential oil and that the mechanism, at least in the case of microorganisms, seems to be caused by their activities on the plasmatic membrane, probably with irruption.

The plasmatic membrane loses its integrity and thus its selective permeability.

Terpenic compounds or terpenoids are active against bacteria, fungi, viruses and protozoa. Williams (1996) described on terpinen-4-ol in the essential oil of tea its activity against Candida albicans and Pseudomonas aeruginosa. This is higher in activity than the eucalyptus's essential oil in which 1.8-cineol is the major compound.
Terpinen-4-ol has high antimicrobial activity (Balacs, 1997), with a higher potential than citronella and caryophyllenes present in the essential oil of E. citriodora.

Results of this work indicated that the essential oil of $E$. cinerea could be highly promising as an alternative in the control of the dengue virustransmitting mosquito in programs for insect control. Such a possibility has the advantage of having the least impact on the environment when compared with impact (side effects) caused by currently used pyretroid insecticides.

\section{Effect of $E$. cinerea essential oil homeopathy on the life cycle of $A$. aegypti}

Mean number of larvae was affected by the homeopathy of $E$. cinerea essential oil when larvae were incubated for 12 days. Dynamizations 6, 9 and $12 \mathrm{CH}$ significantly decreased the mean number of larvae by 11,5 and $7.5 \%$, respectively (Fig. 3). Dynamizations $3 \mathrm{CH}$ and $30 \mathrm{CH}$ were not different from control. Results, however, did not necessarily show that total number of larvae was affected; rather, they showed the number of larvae maintained in this stage during a mean 12-day incubation. In other words, data showed that homeopathic drug accelerated the time spent between the larva and the pupa stage; or rather, as a rule, larvae remained for a lesser period in the larva stage.

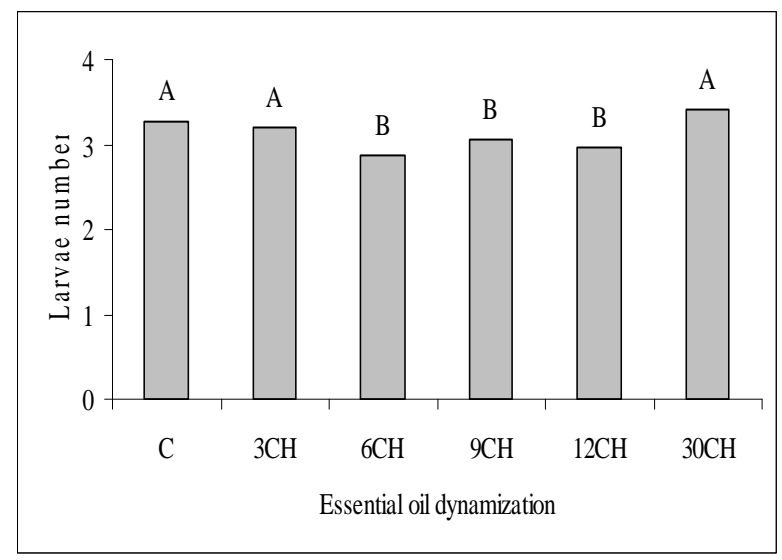

Figure 3 - Mean number of Aedes aegypti larvae during a 12-day incubation period according to different dynamization homeopathies of Eucalyptus cinerea essential oil. Means following by the same capital letters between the columns do not statistically differ by Scott Knott test at 5\% probability. 
Besides the interpretations above, another factor is worth considering. An interesting phenomenon occurs when biological responses in living beings are observed with regard to homeopathic dynamization (Fig. 3). Several authors (Davenas et al., 1988; Godoy, 1988; Bastide, 2004 e 2006, Fazolin et al., 2000; Castro, 2002, Bonato and Silva, 2003, 2006, Bonato 2007) have reported alternation in the physiological expression (cyclic rise and fall) with regard to dynamization.

Although science still has to explain this behavior, it seems to be related to the rhythmic movement of nature (Pongratz, 1998, Bonato, 2004, Bastide, 2004 e 2006) and to the similitude law between the homeopathic solution and the organism that receives it (Vithoulkas, 1997, Bastide, 2006, Bonato, 2004a, 2004b; Bonato and Peres Peres, 2007). Physiological responses to different homeopathic dynamizations of the same homeopathy are almost cyclical and rhythmical and not linear (Kolisko and Kolisko, 1978). Mean pupae number was not affected by the dynamized homeopathic drugs, although a trend seemed to exist for a lesser rate in dynamization 30CH (Fig. 4). Mean adult numbers changed only for dynamization $30 \mathrm{CH}$.

Data suggested that essential oil homeopathic drug in dynamization $30 \mathrm{CH}$ decrease the mean number of production cycles of the female adult mosquito (Fig. 5).

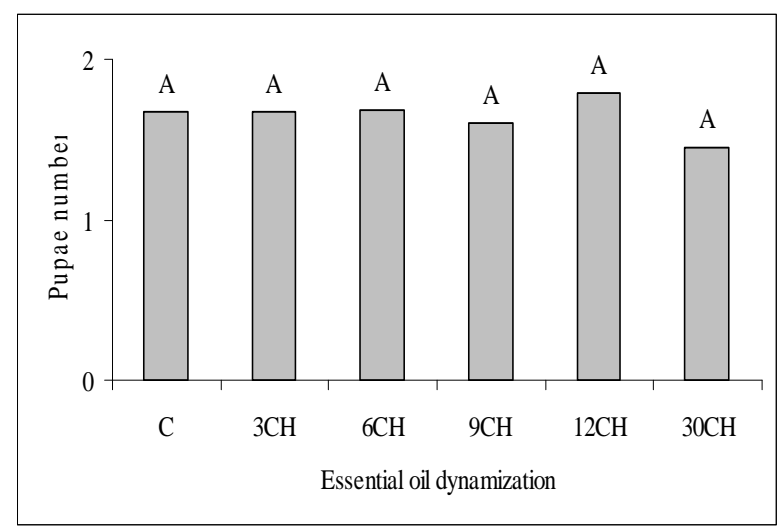

Figure 4 - Mean number of Aedes aegypti pupae during the 12-day incubation period according to different dynamization homeopathies of Eucalyptus cinerea essential oil. Means followed by the same capital letters between the columns do not statistically differ by Scott Knott test at $5 \%$ probability.

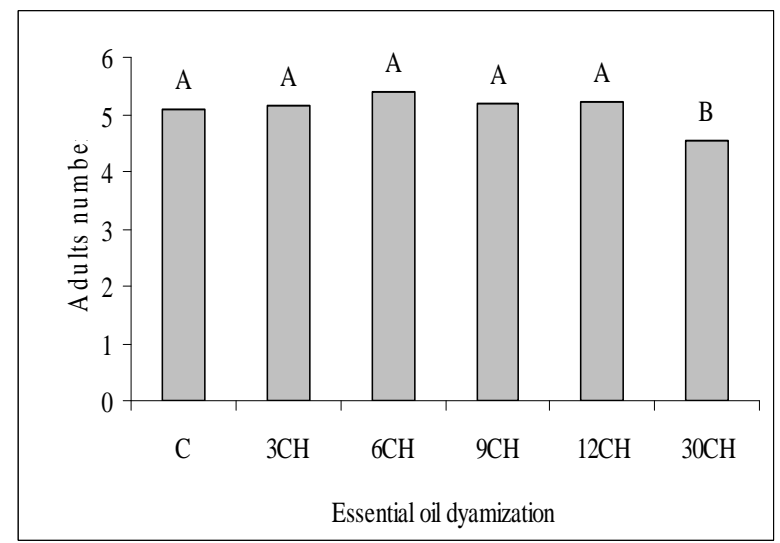

Figure 5 - Mean number of Aedes Aegypti adults during 12-day incubation with regard to different homeopathic dynamizations of Eucalyptus cinerea essential oil. Means followed by the same capital letters between the columns do not differ statistically by Scott Knott test at $5 \%$ probability. 


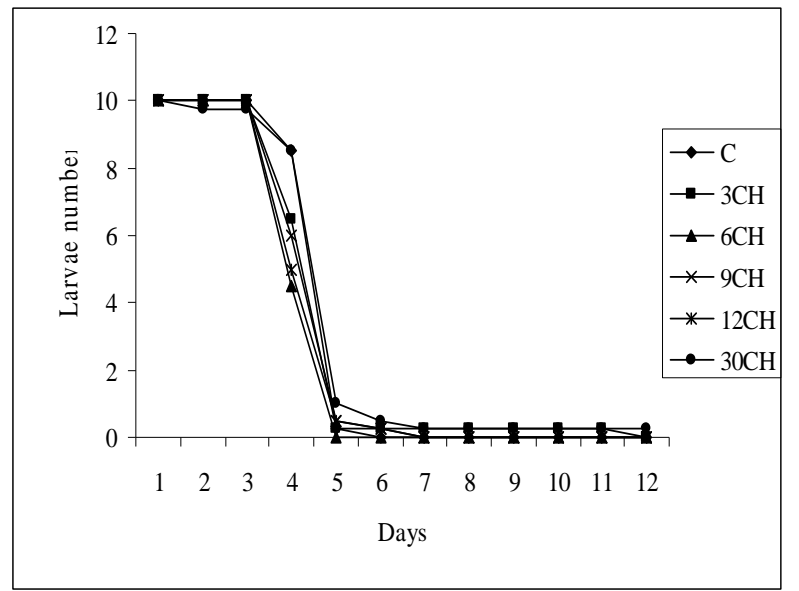

Figure 6 - Daily mean number of Aedes aegypti larvae in incubation medium under different homeopathic dynamizations of Eucalyptus cinerea essential oil ( $\mathrm{p}<0.001$ by $\mathrm{F}$ test).

Results could have practical effects since, as time evolved, less adult females was produced, with subsequent less egg laying and less rate in the production of adult insects.

The statistical interaction occurred between homeopathic dynamizations and time for variables: number of larvae $(\mathrm{p}<0.001)$ (Fig. 6), number of pupae $(p<0.001)$ (Fig. 7) and number of adults $(p<0.001)$ (Fig. 8). The number of larvae during the first three days was very similar to that among the treatments (Fig. 6). Higher differences among the treatments were reported on the fourth day. Control and homeopathic treatment in dynamization $30 \mathrm{CH}$ showed higher number of larvae than that in other treatments. With the exception of $30 \mathrm{CH}$, all the homeopathic treatments accelerated the larva stage towards the pupa stage. Results suggested that all the homeopathies (with the exception of dynamization $30 \mathrm{CH}$ ) somewhat increased the larvae's physiological metabolism and made them pass faster to the pupa phase. The number of pupae during the fourth incubation day of $A$. aegypti was higher than that in homeopathy treatments. The only exceptions were control and dynamization $30 \mathrm{CH}$, as expected, due to reasons above. A fast decrease in the number of pupae occurred on the seventh day owing to the formation of adults (Fig. 7).

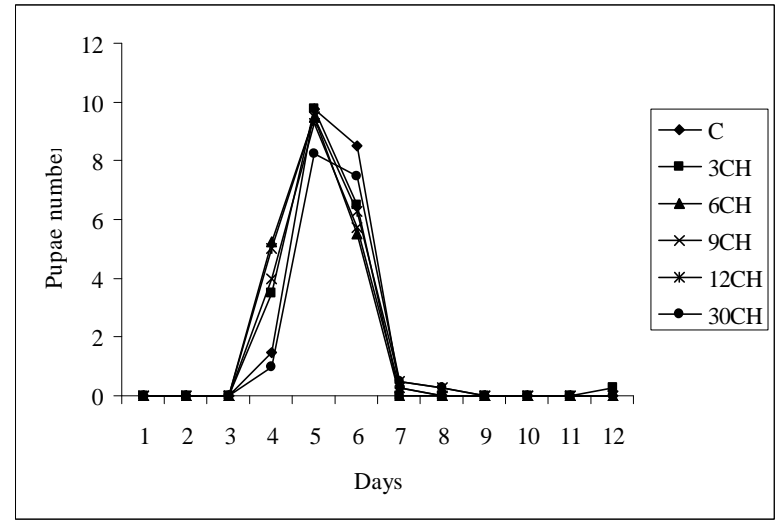

Figure 7 - Daily mean number of Aedes aegypti pupae in incubation medium under different homeopathic dynamizations of Eucalyptus cinerea essential oil ( $\mathrm{p}<0.001$ by $\mathrm{F}$ test). 
The number of adult mosquitoes only changed after the fifth day of the experiment (Fig. 8). Control and dynamization $30 \mathrm{CH}$ presented on the sixth day the least mean number of adults. Treatments had similar kinetics as from the sixth day of incubation. In fact, the same trend followed, excepting homeopathic treatment $30 \mathrm{CH}$. The latter treatment decreased the mean number of adult insects since the sixth till the twelfth day. Data showed (Fig. 5) that as a rule, homeopathic treatment of essential oil $30 \mathrm{CH}$ had lesser mean rates in the number of full adults. It is important to highlight that a certain homeopathic treatment in several homeopathic dynamizations may lead towards different physiological responses (Davenas et al., 1988; Vithoulkas, 1997; Bonato, 2004a, 2004b, 2007; Casali et al., 2006). The use of several dynamizations in homeopathic medicines is mandatory in the experiments (Kolisko and Kolisko, 1978). When there is similarity between the homeopathic dynamization and the organism, the latter's response is positive. However, when no similarity exists between the homeopathy and the organism, disorders may occur in the organism's metabolic system, such as inhibition in physiological metabolism, as described by Bonato and Silva (2003).

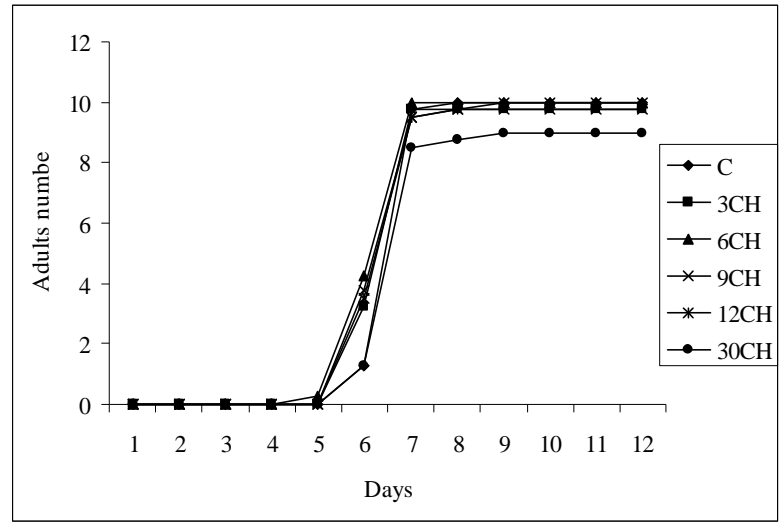

Figure 8 - Mean daily number of Aedes aegypti adults in incubation medium under different homeopathic dynamizations of Eucalyptus cinerea essential oil ( $\mathrm{p}<0.001$ by $\mathrm{F}$ test).

\section{RESUMO}

O efeito larvicida e homeopático do óleo essencial de Eucalyptus cinerea sobre o Aedes aegypti foi aqui analisado. Foram estudados os efeitos larvicida (doses de 0 a $100 \quad \mathrm{mg} \mathrm{mL}^{-1}$ ) e homeopático (dinamizações $3 \mathrm{CH}, 6 \mathrm{CH}, 9 \mathrm{CH}$, $12 \mathrm{CH}$ e $30 \mathrm{CH}$ ) do óleo essencial de E. cinerea sobre os estádios de desenvolvimento do Aedes aegypti. $\mathrm{O}$ óleo essencial apresentou grande poder larvicida com $\mathrm{LC}_{50}$ e $\mathrm{LC}_{90}$ de $0,38 \mathrm{mg} \mathrm{mL}$ e 0,27 $\mathrm{mg} / \mathrm{mL}$, respectivamente. As homeopatias do óleo essencial, de modo geral, influenciaram nos estádios de desenvolvimento do A. aegypti. As dinamizações $6 \mathrm{CH}, 9 \mathrm{CH}$ e $12 \mathrm{CH}$ reduziram o número médio de larvas em comparação com o controle. O número médio de mosquito foi reduzido pela dinamização homeopática $30 \mathrm{CH}$. Os resultados sugerem que o óleo essencial de E. cinerea tem grande potencial para ser utilizado nos programas de saúde pública para o controle do A. aegypti. A homeopatia do óleo essencial interferiu na biologia do Aedes aegypti e deve ser objeto de estudo em futuros experimentos.

\section{REFERENCES}

Almeida, M. A. Z. et al. (2003), Tratamentos homeopáticos e densidade populacional de Spodoptera frugiperda (J. E. Smith, 1797) Lepdotera: Noctuidae em plantas de milho no campo. Revista Brasileira de Milho e Sorgo, 2, 1-8.

Araújo, E. C. C.; Silveira, E. R.; Lima, M. A. S.; Andrade Neto, M.; Andrade, I. L.; Lima, M. A. A. (2003), Insecticidal Activity and Chemical Composition of Volatile Oils from Hyptis martiusii Benth. J. Agric. Food Chem., 51, 3760-3762.

Balacs, T. (1997), Cineole-Rich Eucalyptus. The International Journal or Aromatherapy, 8, 15-21. 
Bastide, M. (2004), The Corporeal Signifier Theory (A. Lagache): application to the succussed high dilution research and homeopathy. Working Document to prepare the next GIRI Meeting in Brussells, 12-14.

Bastide, M. (2006), Teorias Interpretativas sobre as Ultradiluições e Evidências a Favor. Interpretative Theories about Ultra-Dilutions: Supporting Evidences. Cultura Homeopática, 16, 22-30.

Betti L., Brizzi M., Nani D., Peruzzi M. (1997), Effect of high dilutions of Arsenicum album on wheat seedlings from seeds poisoned with the same substance. Br Hom J.; 86, p.86-89.

Bonato, C. M. (2007), Homeopathy in the host physiology. Fitopatologia Brasileira, 32, 79-82.

Bonato, C. M. (2004), Homeopatia: mecanismo de atuação do medicamento homeopática nas plantas. InSeminário sobre homeopatia na agricultura organica, Medianeira - PR. Anais... Medianeira: UFV. DFT., 4, 45-48.

Bonato, C. M. (2004a), Homeopatia: fisiologia e mecanismo em plantas. In- Seminário sobre ciências básicas em homeopatia, Lages-SC. Anais... Lages: CAV/UDESC; EPAGRI, 4, 38-54.

Bonato, C. M. (2004b), Homeopatia: mecanismo de atuação do medicamento homeopático nas plantas. In-Seminário brasileiro sobre homeopatia na agricultura orgânica, Medianeira - PR. Anais... Medianeira: UFV, DFT, 4, 45-48

Bonato, C. M.; Silva, E. P. (2003), Effect of the homeopathic solution Sulphur on the growth and productivity of radish. Acta scientiarum agronomy, 25, n. 2, 259-263

Bonato, C. M.; Silva, M. H. L. da. (2006), Ação da solução homeopática Natrum muriaticum no crescimento inicial de rabanete. In-Seminário brasileiro sobre homeopatia na agropecuária orgânica, Campos de Goytacazes-RJ. Anais...Campos de Goytacazes: UFV, DFT., 7, 277-289.

Bonato, C.M.; Peres Peres, P. G. (2007), Homeopatia em vegetais. In-Seminário sobre ciências básicas em homeopatia, Lages-SC. Anais...Lages: CAV/UDESC; EPAGRI, 8, 41-59.

Casali, V. W. D.; Castro, D. M. De; Andrade, F. M. C. De; Lisboa, S. P. (2006), Homeopatia bases e princípios. Viçosa: UFV; DFT., 149.

Castro, D. M. (2002), Preparações homeopáticas sobre o crescimento de cenoura, beterraba, capim-limão e chambá. Viçosa, MG-UFV. Tese (Doutorado em Fitotecnia), Universidade Federal de Viçosa, 227.

Cavalcanti, E.S.B.; Morais, S.M.; Lima, M.A. and Santana, E.W.P. (2004), Larvicidal activity of essential oils from Brazilian plants against Aedes aegypti. L. Mem Inst Oswaldo Cruz. 99, 541- 544.

Ciccia, G.; Coussio, J.; Mongelli, E. (2000), Insecticidal activity against Aedes aegypti larvae of some medicinal South American plants. J Ethnopharmacol, 72, 185-189.
CIVES - Centro de Informação em Saúde para Viajantes (2002), Dengue. Available at: www.cives.ufrj.br/informacao/dengue/den-iv.html.

Accessed on 14 February.

Cowan, M. M. (1999), Plant products as antimicrobial agents. Clinical Microbiologycal Reviews, 12, 564582.

Davenas, E.; Beauvais, F.; Amara, J.; Oberbaum, M. et al. (1988), Human basophil degranulation triggered by very dilute antiserum against IgE. Nature, 333, 816-818.

Fazolin, M.; Estrela, J. L. V.; Argolo, V. M. (2000), Utilização de medicamentos homeopáticos no controle de Cerotoma tingomariannus Bechyné (Coleóptera, Chrysomelidae) em Rio branco, Acre. Available at: http://www.hospvirt.org.br/homeopatia/port/bibliotec a/pesquisahomeopatica/embrapa.htm. Accessed on 28 April.

Furtado, R. F.; Lima, M. G. A.De, Andrade Neto, M.; Bezerra, J. N. S.; Silva, M. G. de V. (2005), Atividade larvicida de óleos essenciais contra Aedes aegypti L. (Díptera: Culicidae).

Godoy, M. (1988), As potências em homeopatia: escala de dinamizações de frequencial ascendente. Revista de homeopatia, 53, n.3, 101-105.

Janssen, A. M. (1989), Antimicrobial Activities of Essential Oils - a Pharmacognostical Study. Cidade, 181 f. Tese (Doctor aan de Rijksuniversiteit te Leiden). Faculteit der Wiskunde en Natuutwetenschappen.

Kolisko, E., Kolisko, L., (1978), Agriculture of Tomorrow, 2a Ed. Acorn Press, Bournemouth, England, 321.

Macoris, M.L.G., M.T.M. A.Ndrighetti, L. Takaku, C.M. Glasser, V.C. Garbeloto and J.E. Bracco. (2003), Resistance of Aedes aegypti from the state of São Paulo, Brazil, to organophosphates insecticides. Mem. Inst. Oswaldo Cruz, 98, 703-708.

Markouk M, Bekkouche K, Larhsini M, Bousaid M, Lazrek Hb, Jana M (2000), Evaluation of some Moroccan medicinal plant extracts for larvicidal activity. J Ethnopharmacol, 73, 93-297.

Pongratz, W.; Nograsek, A.; Endler, C. (1998), Highly diluted agitated silver nitrate and wheat seedling development: effect kinetics of process of successive phases. In: Fundamental research in ultra high dilution and Homeopathy. Schulte, J., Endler, P. C. (eds.). Kluwer Academic Publishers: ordrecht, Holanda, 143-154.

Rahuman A.A.; Gopalakrishnan G.; Ghouse B.S.; Arumugam S.; Himalayan, B. (2000), Effect of Feronia limonia on mosquito larvae. Fitoterapia, 71, 553-555. 
Silva, H.H.G. da; Silva, I.G. da; Santos, R.M.G. dos; Filho, E.R. and Elias, C.N. (2004), Larvicidal activity of tannins isolated of Magonia pubescens St. Hil. (Sapindaceae) against Aedes aegypti (Diptera, Culicidae). Rev. Soc. Bras. Med. Trop., 37, 396-399.

Tare, V.; Deshpande, S.; Sharma, R. N. (2004), Susceptibility of Two Different Strains of Aedes aegypti (Diptera: Culicidae) to Plant Oils. Entomol. Soc. of Amer., Pune-411 008.

Thomas, T. G.; Rao, S.; Lal, S. (2004), Mosquito Larvicidal Properties of Essencial Oil of na Indigenous Plant, Ipomoea cairica Linn. Jpn. J. Infect. Dis., 57, 176-177.

Tsao R, Romanchuk Fe, Peterson Cj, Coast Jr. (2002), Plant growth regulatory effect and insecticidal activity of extracts of tree of Haven (Atlanthus altissima L.). BMC Ecol., 2, 1-8.
Vithoulkas, G. (1997), Homeopatia: ciência e cura. Trad. Sônia Regis. 10 ed. São Paulo: Cultrix, 436.

Williams, L. (1996), Ranking Antimicrobial Activity. The International Journal of Aromatherapy, 4, 32-35.

Wirth, M.C. and G.P. Georghiou. (1999), Selection and caracteriszation of temephos in a population Aedes aegypti from Tortola, British Virtigin Island. J. Am. Mosq. Control Assoc., 15, 315-320.

World Health Organization. (2004), Dengue bulletin: Situation of dengue/dengue haemorrhagic fever in SEA countries.
Received: October 02, 2007; Revised: August 21, 2008; Accepted: October 01, 2009. 